\title{
ANALISIS PEMASANGAN FILTER PASIF DAN AKTIF TERHADAP KANDUNGAN HARMONISA DAN RUGI-RUGI DAYA GARDU DISTRIBUSI KA 2085 DI PT. PLN (Persero) DISTRIBUSI BALI RAYON MENGWI
}

I Putu Budi Aryawan ${ }^{1}$, Antonius lbi Weking ${ }^{2}$, I Wayan Rinas ${ }^{3}$

Program Studi Teknik Elektro, Fakultas Teknik, Universitas Udayana Denpasar - Bali Email : budiaryawan1@gmail.com ${ }^{1}$, tony@ee.unud.ac.id ${ }^{2}$, rinas@unud.ac.id $^{3}$

\section{ABSTRAK}

Pengoperasian beban-beban nonlinear dapat menimbulkan distorsi harmonisa dalam bentuk gelombang tegangan dan arus yang mengakibatkan kondisi sistem kelistrikan tidak normal. Kandungan THD (Total Harmonics Distortion) arus yang berlebih dapat menyebabkan kualitas daya sistem menjadi lebih buruk, sehingga menyebabkan faktor daya sistem menjadi lebih rendah. Filter aktif dan filter pasif yang bertujuan untuk meredam harmonisa yang muncul. Analisis THD hasil simulasi dan pengukuran sesuai dengan standar IEEE 519-2014 yang ditentukan dan analisis perancangan filter pasif dan filter aktif yang tepat untuk menekan distorsi harmonisa. Hasil analisis menunjukkan pemasangan filter aktif menyebabkan kandungan $T H D$ arus dan tegangan telah sesuai dengan standar IEEE 519-2014 yang ditentukan yaitu $\leq 12 \%$ dan $5 \%$. Penggunaan filter pasif dan aktif dapat menurunkan kandungan THDi masing-masing menjadi $8,45 \%$ dan 3,07\%. Sedangkan untuk THDv turun masing-masing menjadi 3,68\% dan 3.45\% dimana sudah memenuhi standar IEEE 519-2014. Rugi-rugi daya menurun masing-masing menjadi sebesar 4,36 kW dan 3,86 kW. Pemasangan filter aktif lebih bagus untuk menurunkan THD (Total Harmonics Distortion) dan rugi-rugi daya pada transformator KA 2085.

Kata kunci : Harmonisa, filter aktif, filter pasif dan rugi - rugi daya

\begin{abstract}
Operation of nonlinear loads can cause harmonic distortion in the voltage and current waveforms that result in abnormal electrical system condition. Content THD (Total Harmonics Distortion) an excess flow can cause power quality systems become worse, thus causing the system power factor is lower. Active filter and Passive filter which aims to reduce harmonics that arise. Analysis THD simulation and measurement results in accordance with IEEE 519-2014 and analysis designing of a passive filter and active filter is right to suppress harmonic distortion. The analysis shows that the installation of active filters causes the current and voltage THD contents to comply with the standard IEEE 519-2014 standards is $\leq 12 \%$ and $5 \%$. The use of passive and active filters can reduce THDi content to $8.45 \%$ and $3.07 \%$, respectively. While for THDV decreased respectively to $3.68 \%$ and $3.45 \%$ which already meet the IEEE 519-2014 standards. Power losses decreased respectively to $4.36 \mathrm{~kW}$ and $3.86 \mathrm{~kW}$. Installation of active filters is better for reducing THD (Total Harmonics Distortion) and power losses in KA 2085 transformers.
\end{abstract}

Keywords: Harmonics, active filters, passive filters and power losses

\section{PENDAHULUAN}

Salah satu permasalahan kualitas daya listrik adalah permasalahan harmonisa. Timbulnya harmonisa pada sistem tenaga listrik salah satunya ditimbulkan oleh alat-alat yang mempunyai impedansi nonlinier seperti penyearah (rectifier), pengubah frekuensi (frequency converter) dan lampu dengan pelepasan gas (gas discharge lamp).
Banyaknya pengoperasian beban nonlinier pada sistem tenaga listrik telah membuat arus sistem menjadi sangat terdistorsi dengan presentase kandungan THD (Total Harmonic Distortion) yang sangat tinggi.

Gardu distribusi KA2085 terletak di Br. Padang Badung Bali, daya terpasangnya sebesar 160 kVA melayani 54 pelanggan. Sesuai kapasitas transformator 160 kVA dan 
rasio hubung singkat transformator, standard harmonisa yang harus dimiliki menurut standard IEEE 519-2014 yaitu $\leq 12,0 \%$ (THD arus) dan $\leq 5,0 \%$ (THD tegangan) [1].

Sehingga dilakukan analisis mengenai pemasangan filter aktif dan filter pasif dan pengaruhnya terhadap kandungan harmonisa dan rugi-rugi daya pada transformator KA 2085.

\section{KAJIAN PUSTAKA}

\subsection{Pengertian Harmonisa}

Harmonisa adalah gejala pembentukan gelombang sinusoidal dengan frekuensi yang merupakan perkalian bilangan bulat dengan frekuensi dasarnya. Arus yang tidak sinusoida ini dapat menimbulkan banyak dampak negatif, baik bagi pelanggan maupun PLN (power provider). Kerugian yang diakibatkan oleh harmonisa mencangkup aspek teknis, biaya dan keandalan [2].

\subsubsection{Pengaruh harmonisa dalam sistem tenaga listrik \\ Ada beberapa pengaruh yang menim-} bulkan panas lebih pada trafo ketika arus beban mengandung harmonisa yaitu rugi tembaga dan rugi arus Eddy [3].

Rugi tembaga adalah terjadinya pemanasan yang terjadi pada kawat tembaga kumparan transformator. Adanya aliran arus yang berlebih yang melewati nilai resistansinya dapat menyebabkan terjadinya pemanasan pada kawat tembaga masing-masing kumparan.

Eddy current loss (rugi arus Eddy) yaitu rugi-rugi yang terjadi pada inti besi akibat adanya arus pusar. Arus induksi yang mengalir pada kumparan dan inti besi dapat menyebabkan pemanasan berlebih pada transformator. Komponen dari rugi-rugi ini meningkat dengan kuadrat dari frekuensi arus penyebab Eddy current loss.

\subsubsection{Sumber Harmonisa}

Terdapat dua jenis beban pada sistem tenaga listrik yaitu beban linier dan beban nonlinier. Beban linier memberikan bentuk gelombang keluaran linier artinya arus yang mengalir sebanding dengan perubahan tegangan. Sedangkan beban nonlinier memberikan bentuk gelombang keluaran arus yang tidak sebanding dengan tegangan dasar, sehingga gelombang arus maupun tegangannya tidak sama dengan gelombang masukannya seperti yang diperlihatkan pada Gambar 1 [4].

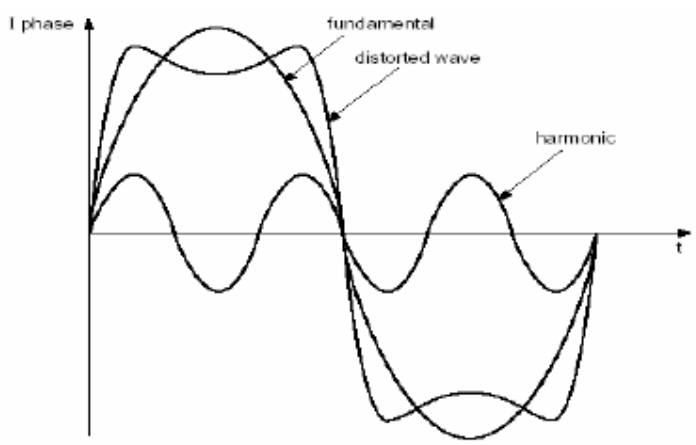

Gambar 1. Gelombang fundamental, gelombang harmonisa dan gelombang terdistorsi [3].

\subsubsection{Standard Harmonisa pada sistem tenaga listrik \\ Berdasarkan IEEE standard 519-2014} berisikan tentang nilai-nilai yang dijadikan sebagai batas maksimum distorsi harmonisa tegangan yang direkomendasikan terhadap sistem seperti yang ditunjukkan pada Tabel 1 dan 2 berikut.

Tabel 1. Voltage Distortion Limits [1].

\begin{tabular}{|c|c|c|}
\hline Bus Voltage $(\mathrm{V})$ at PCC & Individual Harmonic $(\%)$ & Total Hamonic Distortion $(\%)$ \\
\hline $\mathrm{V} \leq 1 \mathrm{kV}$ & 5.0 & 8.0 \\
\hline $1 \mathrm{kV}<\mathrm{V}<69 \mathrm{kV}$ & 3.0 & 5.0 \\
\hline $69 \mathrm{kV}<\mathrm{V}<161 \mathrm{kV}$ & 1.5 & 2.5 \\
\hline $161 \mathrm{kV}<\mathrm{V}$ & 1.0 & 1.5 \\
\hline
\end{tabular}

Tabel 2. Curent Distortion Limits for System Rated $120 \mathrm{~V}$ Through 69kV [1].

\begin{tabular}{|c|c|c|c|c|c|c|}
\hline \multicolumn{7}{|c|}{ Maximum Harmonic Current Distortion in Percent of $I_{L}$} \\
\hline \multicolumn{7}{|c|}{ Individual Harmonic Order (odd harmonic), 20} \\
\hline $\mathrm{Isc}_{\mathrm{L}}$ & $3 \leq \mathrm{h} \leq \mathrm{Il}$ & $11 \leq h \leq 17$ & $17 \leq h \leq 23$ & $23 \leq h \leq 35$ & $35 \leq h \leq 50$ & THID (\%) \\
\hline$<20^{\circ}$ & 4.0 & 2.0 & 1.5 & 0.6 & 0.3 & 5.0 \\
\hline $20<50$ & 7.0 & 3.5 & 2.5 & 1.0 & 0.5 & 8.0 \\
\hline $50<100$ & 10.0 & 4.5 & 4.0 & 1.5 & 0.7 & 12.0 \\
\hline $100<1000$ & 12.0 & 5.5 & 5.0 & 2.0 & 1.0 & 15.0 \\
\hline$>1000$ & 15.0 & 7.0 & 6.0 & 2.5 & 1.4 & 20.0 \\
\hline
\end{tabular}

\subsubsection{Rasio Hubung Singkat}

Perhitungan rasio hubung singkat (Short-Circuit Ratio) harus diketahui terlebih dahulu nilai arus hubung singkat (Short-Circuit Current) dan arus beban (Load Current) [5].

$=\frac{S \times 100^{I_{S C}}}{\% Z \times \sqrt{3} \times 4}$ 
Keterangan :

$I_{S C}$ adalah Arus hubung singkat $(A)$

$$
=\frac{P}{P F x \sqrt{3 x V}}
$$

Keterangan :

$I_{L} \quad$ adalah Arus beban $(A)$

$P$ adalah Daya Aktif $(W)$

$P_{F}$ adalah Power Factor

Sehingga Short Circuit Ratio $=\frac{I_{S C}}{I_{L}}$

\subsection{Rugi-Rugi Daya}

\subsubsection{Rugi rugi daya pada transformator}

Rugi-rugi suatu transformator secara teknis dapat disebut sebagai load loss $\left(P_{L L}\right)$. Terdapat dua komponen dalam perhitungan load loss yaitu rugi-rugi tembaga $\left(I^{2} R\right)$ dan Eddy-Current Loss $\left(P_{E C}\right)$. Dalam satuan per unit (p.u) load loss dapat di hitungan dengan Persamaan 3 [6].

$$
P_{L L} \quad=\sum I_{h}^{2}+\left(\sum I_{h}^{2} x h^{2}\right) x P_{E C-R}(p v)
$$

Keterangan :

$P_{E C-R}$ adalah Eddy Current Loss Factor

$h$ adalah Harmonisa (\%)

$I_{h} \quad$ adalah Arus Harmonisa $(A)$

Faktor Eddy current loss dapat dilihat pada

\begin{tabular}{|c|c|c|c|}
\hline Type & MVA & Voltage & $P_{\text {ecR }}(\%)$ \\
\hline \multirow{3}{*}{ Dry } & $\leq 1$ & . & 3.8 \\
\hline & $\leq 1.5$ & $5 \mathrm{kV}$ (High Voltage) & 12.20 \\
\hline & $\leq 1,5$ & $15 \mathrm{kV}$ (Hight Voltage) & 9.15 \\
\hline \multirow{3}{*}{ Oil-filled } & $\leq 2.5$ & 480 V (Low Voltage) & 1 \\
\hline & $2.5-5$ & $480 \mathrm{~V}$ (Low Voltage & 1.5 \\
\hline & 25 & 480 V (Low Voltage $)$ & 9.15 \\
\hline
\end{tabular}
Tabel 3 sebagai berikut.

\subsubsection{Rugi rugi daya pada Saluran}

Mengalirnya arus harmonisa $\left(I_{r m s}\right)$ pada penghantar, menyebabkan terjadinya penambahan panas sehingga terjadi peningkatan rugi-rugi $I^{2} R$ pada penghantar tersebut. Rugirugi daya saluran dengan kandungan harmonisa dapat dihitung menggunakan persamaan 4.

$$
P_{\text {Loss }}=\sum_{n=2}^{\infty} I_{n}^{2} R_{n}
$$

\subsection{Filter Harmonisa}

Filter harmonisa adalah suatu teknologi elektronika daya untuk menghasilkan komponen arus spesifik yang bertujuan untuk meredam arus harmonisa yang dihasilkan oleh beban nonlinier.

\subsubsection{Filter aktif}

Prinsip dasar dari Filter Aktif menggunakan teknologi elektronika daya untuk menghasilkan komponen arus spesifik yang bertujuan untuk menggagalkan komponen arus harmonisa yang dihasilkan oleh beban nonlinear [7].
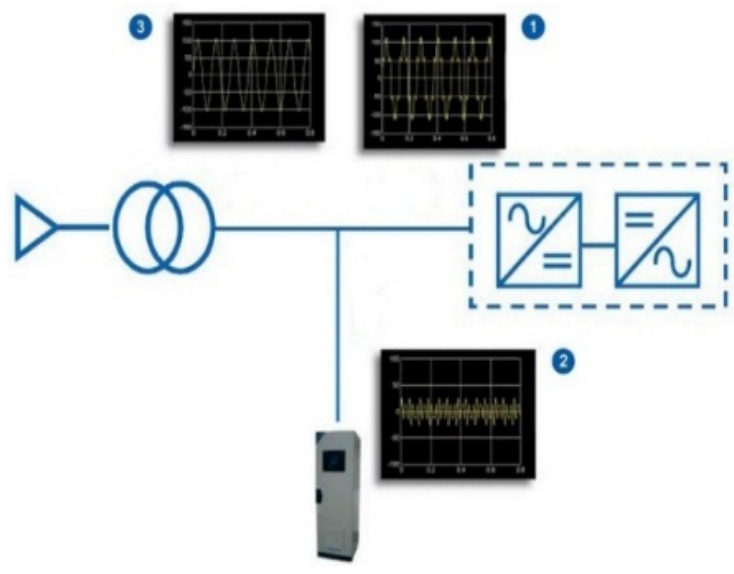

Gambar 2. Rangkaian Filter Aktif

Filter aktif harmonisa mirip dengan generator arus harmonisa yang menggunakan elektronika daya untuk mengukur harmonisa yang di hasilkan oleh beban nonlinier kemudian akan menyuntikkan arus harmonisa berlawanan dari amplitudo yang sama. Sehingga arus yang di salurkan oleh sumber listrik akan tetap sinusoidal karena harmonisa akan saling meniadakan.

\subsubsection{Filter pasif}

Filter ini sebagian besar dirancang untuk mengalihkan harmonisa arus yang tidak di inginkan dalam sistem tenaga [2].

Input 


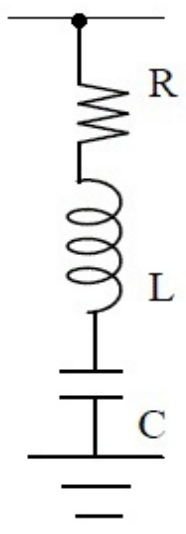

Gambar 3. Rangkaian Filter Pasif Single Tuned

Parameter utama yang harus dipertimbangkan dalam pemilihan $R, L, C$ pada saat perancangan filter pasif adalah quality factor $(Q)$, nilai ini akan menentukan ketajaman penalaan. Pada orde harmonisa prekuensi rendah biasanya Q berharga antara 30 sampai dengan 60 .

\subsubsection{Perancangan filter}

Menentukan nilai kapasitansi kapasitor sesuai kebutuhan kompensasi faktor daya [8].

$$
Q_{C}=P\left(\tan \theta_{1^{-}} \quad \tan \theta_{2}\right)
$$

\section{Keterangan :}

$P \quad$ adalah Daya beban nonlinier

$\theta_{1} \quad$ adalah faktor daya pada sistem

$\theta_{1} \quad$ adalah faktor daya normal

$\mathrm{Q}_{\mathrm{c}} \quad$ adalah perbaikan faktor daya

Menentukan nilai kapasitor

$$
\begin{aligned}
\mathrm{X}_{\mathrm{C}} & =\frac{V^{2}}{Q_{C}} \\
\mathrm{C} & =\frac{1}{2 \pi f X c}
\end{aligned}
$$

Keterangan :

C adalah nilai kapasitor

$V$ adalah tegangan pada saluran $(\mathrm{kV})$

$Q_{c}$ adalah perbaikan faktor daya

$X_{C}$ adalah nilai kapasitor pada simulasi

$f$ adalah frekuensi fundamental $(\mathrm{Hz})$ resonansi

Nilai induktor dicari berdasarkan prinsip

$$
\begin{aligned}
\mathrm{L} & =\frac{1}{(C)(2 \pi f n)^{2}} \\
\mathrm{X}_{\mathrm{L}} & =2 \pi f L
\end{aligned}
$$

Keterangan :

$L \quad$ adalah Nilai Induktor

C adalah Nilai kapasitor

$n$ adalah Nilai orde harmonisa yang akan dieliminasi

$X_{L} \quad$ adalah Nilai induktor pada simulasi Menentukan nilai resistor

$$
R=\frac{n \cdot X_{L}}{Q}
$$

$Q \quad$ adalah Ukuran ketajaman filter

$R$ adalah Nilai resistor

$X_{L}$ adalah Nilai induktor pada simulasi

$n$ adalah Nilai orde harmonisa yang akan dieliminasi

\subsection{ETAP (Electric Transient and analysis Program)}

ETAP merupakan perangkat lunak yang dapat mendukung sistem tenaga listrik. Perangkat ini mampu bekerja dalam offline untuk simulasi tenaga listrik dan online untuk pengeIolaan data real time. Harmonic analysis pada ETAP memberikan fasilitas untuk mensimulasikan, memodelkan dan menganalisis fenomena harmonisa pada sistem tenaga listrik.

\section{METODE PENELITIAN}

Data yang digunakan dalam penelitin ini merupakan data primer yang bersumber dari pengukuran langsung harmonisa pada seluruh beban tegangan rendah PT. PLN (Persero) Rayon Mengwi yang bersumber dari gardu distribusi KA 2085. Serta beberapa data sekunder yang bersumber dari buku-buku yang berhubungan dengan topik.

Berikut tahapan proses analisis :

1. Pengumpulan data beban masingmasing pelanggan PT. PLN (Persero), data penghantar JTR dan SR, data Transformator KA 2085, dan data konfigurasi JTR dan SR,

2. Rekapitulasi nilai harmonisa masing-masing beban berdasarkan data beban masing-masing pelanggan,

3. Menghitung rugi-rugi daya pada Transformator KA 2085, untuk penggunan filter pasif dan filter aktif.

\section{HASIL DAN PEMBAHASAN \\ 4.1 Hasil Pengukuran Beban Pada KA 2085}


Tranformator Distribusi KA 2085 mempunyai beban sebagai berikut:

Tabel 4. Hasil pengukuran power faktor pada KA 2085

\begin{tabular}{|c|c|c|c|}
\hline \multirow{2}{*}{ Waktu } & \multicolumn{3}{|c|}{ Hasil Pengukuran } \\
\cline { 2 - 4 } & $\mathrm{P}_{\mathrm{F}} \mathrm{R}$ & $\mathrm{P}_{\mathrm{F}} \mathrm{S}$ & $\mathrm{P}_{\mathrm{F}} \mathrm{T}$ \\
\hline 08.00 & 0,88 & 0,87 & 0,91 \\
\hline
\end{tabular}

Tabel 5 Hasil pengukuran arus dan tegangan pada KA 2085

\begin{tabular}{|c|c|c|c|c|c|c|}
\hline \multirow{3}{*}{ Waktu } & \multicolumn{7}{|c|}{ Hasil Pengukuran } \\
\cline { 2 - 7 } & $\begin{array}{c}\mathrm{R}-\mathrm{N} \\
(\mathrm{V})\end{array}$ & $\begin{array}{c}\mathrm{S}-\mathrm{N} \\
(\mathrm{V})\end{array}$ & $\begin{array}{c}\mathrm{T}-\mathrm{N} \\
(\mathrm{V})\end{array}$ & $\begin{array}{c}\mathrm{I}_{\mathrm{R}} \\
(\mathrm{A})\end{array}$ & $\begin{array}{c}\mathrm{I}_{\mathrm{S}} \\
(\mathrm{A})\end{array}$ & $\begin{array}{c}\mathrm{I}_{\mathrm{T}} \\
(\mathrm{A})\end{array}$ \\
\hline 08.00 & 227,2 & 242,3 & 221,0 & 54,1 & 31,3 & 84,9 \\
\hline
\end{tabular}

\subsection{Rasio hubung singkat}

Arus hubung singkat (ISC) dapat dihitung dengan Persamaan 1 sebagai berikut.

$$
I_{S C}=\frac{160 \times 100}{4 \times \sqrt{3} \times 0,4}=5714,3 \mathrm{~A}
$$

Arus permintaan maksimal $\left(I_{L}\right)$ dapat dihitung dengan Persamaan 2 sebagai berikut. $P_{\text {fasa } R}=54,1 \times 227,2 \times 0,88=10816,6 \mathrm{~W}$ $P_{\text {fasa }}=31,3 \times 242,3 \times 0,87=6598,1 \mathrm{~W}$ $P_{\text {fasa } T}=84,9 \times 221,0 \times 0,91=17074,2 \mathrm{~W}$

$$
I_{L}=\frac{84,5}{0,89 x \sqrt{3} x 0,4}=57,5 \mathrm{~A}
$$

Jadi

$$
\frac{I_{S C}}{I_{L}}=\frac{5714,3}{57,5}=99,4
$$

Sehingga standard yang digunakan menurut IEEE standard 519-2014 adalah sebagai berikut.

Keterangan :

ISC/IL adalah $50<100$

THD adalah $12,0 \%$

Orde $<11$ adalah 10,0\%

Orde $11-17$ adalah $4,5 \%$

Orde $17-23$ adalah 4,0\%

Orde 23-35 adalah 1,5\%

Orede $>35$ adalah $0,7 \%$

Standard harmonisa tegangan menggunakan tegangan sisi sekunder trafo yaitu $400 \mathrm{~V}$ atau lebih kecil dari 69V sehingga standard yang digunakan menurut IEEE standard 519-2014 THDV adalah 5\%.

\subsection{Hasil Simulasi Menggunakan Mode Harmonic Analysis \\ Data hasil running menunjukan} kandungan harmonisa pada transformator yaitu $T H D_{V} 7,31$ (belum memenuhi standard) dan $T H D, 18,52$ (belum memenuhi standard) sedangkan untuk power factor dari transformator KA2085 yaitu sebesar 89\%. 


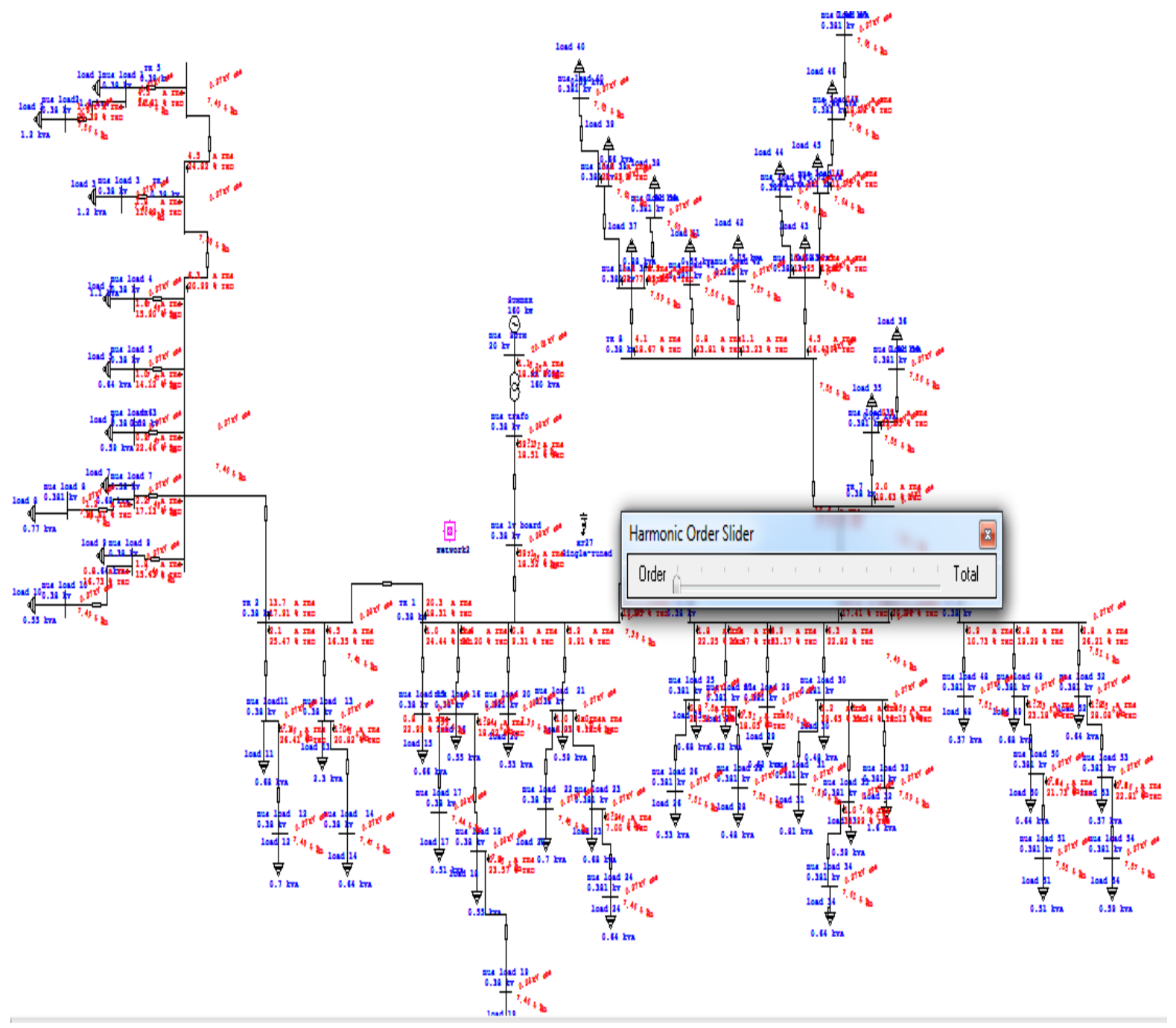

Gambar 4. Tampilan Hasil Runing Program ETAP PowerStation

\subsection{Perancangan Filter Harmonisa}

Terlebih dahulu harus menentukan orde harmmonisa yang akan dieliminasi yaitu terletak pada orde ke 5. Perhitungan dapat dilihat sebagai berikut.

Daya reaktif untuk memperbaiki faktor daya dapat dihitung dengan Persamaan 5 sebagai berikut.

$$
\begin{aligned}
Q_{C} & =P\left(\tan \theta_{1}-\tan \theta_{2}\right) \\
& =34(\tan 27,13-\tan 11,47) \\
& =10,54 \mathrm{kVAR}
\end{aligned}
$$

Nilai Kapasitor pada simulasi dapat dihitung dengan Persamaan 6 dan 7 sebagai berikut.

$$
X_{C}=\frac{0,14}{0,011}=12,7 \Omega
$$

$$
C=\frac{1}{2.3,14.50 .12,7}=2,5 \times 10^{-4} \mathrm{~F}
$$

Nilai induktor pada simulasi dapat dihitung dengan Persamaan 8 dan 9 sebagai berikut.

$$
\begin{gathered}
L=\frac{1}{\left(2,5 \times 10^{-4}\right) \cdot(2.3,14 \cdot 50.5)^{2}}=1,6 \times 10^{-3} H \\
X_{L}=2.3,14 \cdot 50.1,6 \times 10^{-3}=0,5 \Omega
\end{gathered}
$$

Nilai resistor pada simulasi dapat dihitung dengan Persamaan 10 sebagai berikut.

Perancangan filter pasif dan filter aktif, nilai $Q$ yang digunakan adalah 20 karena distorsi harmonisa yang besar terdapat pada orde 20 ke bawah. 


$$
R=\frac{5 \cdot(0.5)}{20}=0,145 \Omega
$$

Sehingga komponen filternya sebagai berikut.

Tabel 6. Nilai Komponen Filter

\begin{tabular}{|c|c|}
\hline Parameter & Nilai \\
\hline $\mathrm{Q}_{\mathrm{C}}$ & $10,54 \mathrm{kVAR}$ \\
\hline $\mathrm{X}_{\mathrm{C}}$ & $12,7 \Omega$ \\
\hline $\mathrm{C}$ & $2,5 \times 10^{-4} \mathrm{~F}$ \\
\hline $\mathrm{X}_{\mathrm{L}}$ & $0,5 \Omega$ \\
\hline $\mathrm{L}$ & $1,6 \times 10^{-3} \mathrm{H}$ \\
\hline $\mathrm{R}$ & $0,145 \Omega$ \\
\hline
\end{tabular}

\subsection{Rugi-Rugi Daya Sebelum Pemasangan} Filter Harmonisa

Berdasarkan data hasil running, dapat dicari nilai rugi-rugi sistem distribusi pada trafo 160 KVA setelah terpengaruh harmonisa seperti dibawah ini.

$$
\begin{aligned}
& S \quad=160 \mathrm{KVA} \\
& \begin{aligned}
\operatorname{Cos} \varphi=0,89 & \\
P_{\text {Base satu fasa }} & =S . \operatorname{Cos} \varphi / \sqrt{3} \\
& =(160 \mathrm{KVA} \times 0,89) / \sqrt{3} \\
& =82,2 \mathrm{~kW}
\end{aligned}
\end{aligned}
$$

Rugi-rugi daya pada transformator setelah terpengaruh harmonisa dapat dicari dengan cara sebagai berikut.

Untuk Orde 1

$$
I_{h 1}(p u)=\frac{I_{h 1}}{I_{1}}=\frac{58,25}{58,25}=1,000 p u
$$

Menggunakan cara yang sama, maka diperoleh arus harmonisa dalam satuan perunit, seperti yang ditunjukan pada Tabel 7 .

Tabel 7. Perhitungan losses pada Trafo

\begin{tabular}{|c|l|l|l|l|}
\hline Orde & \multicolumn{1}{|c|}{$I_{h}$} & \multicolumn{1}{|c|}{$I_{h}(\mathrm{pu})$} & \multicolumn{1}{c|}{$I_{h}{ }^{2}{ }^{2} x_{h}{ }^{2}$} \\
\hline 1 & 57,79 & 1 & 1 & 1 \\
\hline 3 & 0 & 0 & 0 & 0 \\
\hline 5 & 8,54 & 0,147 & 0,021874 & 0,54686 \\
\hline 7 & 5,49 & 0,095 & 0,009025 & 0,442225 \\
\hline 9 & 0 & 0 & 0 & 0 \\
\hline 11 & 0,288 & 0,005 & 0,000025 & 0,003021 \\
\hline 13 & 0,14 & 0,002 & 0,0000061 & 0,001039 \\
\hline 15 & 0 & 0 & 0 & 0 \\
\hline & 0,002 & 3 & 8,0000 & 0,0000002 \\
\hline 17 & 0,001 & 2 & 4 & 6 \\
\hline & 0,0000 & 0,000000000 & 0,0000002 \\
\hline 19 & \multicolumn{5}{|c|}{ Jumlah } & 1,030931 & 1,993146 \\
\hline
\end{tabular}

Berdasakan Tabel 7, maka rugi-rugi beban dapat dihitung menggunakan Persamaan 3 sebagai berikut.

$P_{L L}=1,03093+1.99314 \times 0,01=1,05086 p . u$
Sehingga rugi-rugi $I^{2} R$ bertambah sebesar 0,03093 p.u dan rugi eddy current bertambah sebesar 0,009931 p.u.

Rugi tembaga:

$P_{c u}=0,03093$ p.u $\times 82,2 \mathrm{~kW}=2,54 \mathrm{~kW}$

Rugi eddy current:

$P_{i}=0,009931$ p.u $\times 82,2 \mathrm{~kW}=0,82 \mathrm{~kW}$

Jadi penambahan losses.

$$
P_{L L}=3 .\left(P_{C U}+P_{i}\right)=3 \cdot(2,54+0,82)=10,08
$$

kW

Menghitung rugi-rugi daya saluran akibat pengaruh harmonisa dapat menggunakan Persamaan 4 sebagai berikut.

$$
\begin{aligned}
& I_{\text {rms }} \text { (Arus harmonisa) } \quad=58,92 \mathrm{~A} \text {. } \\
& L \text { (Panjang penghantar })=10 \mathrm{~m} \\
& =0,5096 \Omega / \mathrm{km} \mathrm{x} \\
& 0,01 \mathrm{~km} \\
& =0,01 \Omega \\
& P_{\text {Loss }}=3 \times\left(I_{\text {rms }}\right)^{2} \cdot R \\
& =3 \times(58,92)^{2} \times 0,01 \\
& =53,07 \text { Watt } \\
& =0,053 \mathrm{~kW}
\end{aligned}
$$

Menggunakan cara perhitungan yang

\begin{tabular}{|c|c|c|c|c|}
\hline Tempat & $\begin{array}{c}\text { Standard } \\
\text { IEEE 519- } \\
2014\end{array}$ & $\begin{array}{c}\text { Tanpa } \\
\text { Filter }\end{array}$ & $\begin{array}{l}\text { Filter } \\
\text { pasif }\end{array}$ & $\begin{array}{c}\text { Filter } \\
\text { aktif }\end{array}$ \\
\hline Trafo & $12 \%$ & $18,52 \%$ & $8,45 \%$ & $3,07 \%$ \\
\hline
\end{tabular}
sama seperti di atas, dapat dianalisis untuk masing-masing saluran yang memiliki nilai arus r.m.s $\left(I_{r m s}\right)$.

Total rugi-rugi pada transformator KA 2085 sebelum pemasangan filter yaitu $2,4 \mathrm{~kW}$ (rugi-rugi trafo tanpa beban) $+10,08 \mathrm{~kW}$ (rugirugi trafo dengan beban nonlinier) $+0,16 \mathrm{~kW}$ (rugi-rugi saluran) menjadi 12,64 kW

\subsection{Analisa Sebelum dan Sesudah Pemasangan Filter Aktif dan Pasif Harmonisa \\ Hasil simulasi sebelum dan setelah} penggunaan filter aktif dan pasif harmonisa serta perbandingan terhadap Standar IEEE 519-2014.

Tabel 8. Kandungan THD, pada Transformator KA 2085 
Tabel 8 menunjukan penggunaan filter pasif THD arus dapat diturunkan 10,07\% menjadi 8,45\% (sudah memenuhi standard). Sedangkan penggunaan filter aktif dapat menurunkan THD arus sebesar $15.45 \%$ menjadi 3,07\% (sudah memenuhi standard).

Tabel 9. Kandungan THD, pada Transformator KA 2085

\begin{tabular}{|c|c|c|c|c|}
\hline & $\begin{array}{c}\text { Standad } \\
\text { Tempat }\end{array}$ & $\begin{array}{c}\text { Tanpa } \\
\text { Filter }\end{array}$ & $\begin{array}{c}\text { Filter } \\
\text { pasif }\end{array}$ & $\begin{array}{c}\text { Filter } \\
\text { aktif }\end{array}$ \\
\hline Trafo & $5 \%$ & $7,31 \%$ & $3,68 \%$ & $3,45 \%$ \\
\hline
\end{tabular}

Tabel 9 menunjukan THD tegangan yang turun masing-masing sebesar 3,62 \% dan 3,85\% menjadi 3,68\% (penggunaan filter pasif) dan 3,45 \% ( penggunaan filter aktif).

Tabel 10. Rugi - rugi daya pada transformator KA 2085

\begin{tabular}{|c|c|c|c|}
\hline \multirow{2}{*}{ Tempat } & \multicolumn{3}{|c|}{ Rugi - rugi daya } \\
\cline { 2 - 4 } & $\begin{array}{c}\text { Tanpa } \\
\text { filter (kW) }\end{array}$ & $\begin{array}{c}\text { Dengan filter } \\
\text { pasif (kW) }\end{array}$ & $\begin{array}{c}\text { Dengan filter } \\
\text { aktif (kW) }\end{array}$ \\
\hline Trafo & 12,64 & 4,36 & 2,86 \\
\hline
\end{tabular}
transformator, dimana penggunaan filter pasif menurunkan rugi-rugi transformator sebesar 8,28 kW menjadi 4,36 kW. Sedangkan penggunaan filter akti dapat menurunkan rugi-rugi pada transformator sebesar 9,78 kW menjadi 2,86 kW.

\section{SIMPULAN DAN SARAN}

\subsection{Simpulan}

Kandungan THDi ditransformator distribusi KA 2085 sebelum menggunakan filter harmonisa sebesar $18,52 \%$, untuk nilai $T H D_{V}$ sebesar $7.31 \%$ dimana kondisi tersebut belum memenuhi standard IEEE 519-2014 sedangkan untuk rugi-rugi daya sebesar $12.64 \mathrm{~kW}$.

Penggunaan filter pasif dan aktif dapat menurunkan kandungan THDi masing-masing menjadi $8,45 \%$ dan $3,07 \%$. Sedangkan untuk THDv turun masing-masing menjadi $3,68 \%$ dan $3.45 \%$ dimana sudah memenuhi standar IEEE 519-2014. Rugi-rugi daya menurun masing-masing menjadi sebesar $4,36 \mathrm{~kW}$ dan 3,86 kW.

\subsection{Saran}

Penelitian selanjutnya perlu dikembangkan penggunaan filter hybrid serta perlu menentukan metode utuk dapat memunculkan nilai THDi dan THDV pada setiap fasa di software ETAP.

\section{DAFTAR PUSTAKA}

[1] "IEEE Recommended Practices and Requirements for Harmonic Control Power System," IEEE Std 519-2014, 2014.

[2] W. Rinas, "Analisis Perbandingan Penggunaan Filter Pasif Dan Filter Aktif Untuk Menanggulangi THD Pada Sistem Kelistrikan Di Ruang Puskom Jurusan Teknik Elektro Fakultas Teknik Universitas Udayana". JURNAL TEKNOLOGI ELEKTRO UNUD Vol. 10, No. 1, Januari-Juni 2011.

[3] W. Rinas, "Studi Analisis Dan Derating Akibat Pengaruh THD Pada Gardu Transformator Daya Di Fakultas Teknik Universitas Udayana". JURNAL TEKNOLOGI ELEKTRO UNUD Vol. 11, No. 1, JanuariJuni 2012.

[4] F.C.D.L. Rosa, Harmonic And Power Siystem. USA: Taylor \& Francis Group,LLC. 2006.

[5] J. H. Harlow, Electric Power Transformer Engineering. USA: CRC Press LLC, 2004.

[6] R. C. Dugan, dkk, Electrical Power System Quality, Second Edition. USA: The McGraw-Hill Companies, 2004

[7] A. I. Weking, dkk, "Simulasi Penentuan Penempatan Filter Aktif Shunt Untuk Mendapatkan Distorsi Daya Yang Terkecil Di Blue Point Villa \& SPA". JURNAL TEKNOLOGI ELEKTRO UNUD Vol. 12, No. 2, Juli-Desember 2013.

[8] W.Prasetyadi,R.S.Wibowo,O.Penangsang, "Evaluasi Harmonisa dan Perencanaan Filter Pasif pada Sisi Tegangan $20 \mathrm{kV}$ Akibat Penambahan Beban pada Sistem Kelistrikan Pabrik Semen Tuban". JURNAL TEKNIK ITS Vol. 1, No. 1 (Sept. 2012) ISSN: 2301-9271. 2012. 